University of Nebraska - Lincoln

DigitalCommons@University of Nebraska - Lincoln

USDA Forest Service / UNL Faculty Publications U.S. Department of Agriculture: Forest Service -National Agroforestry Center

2013

\title{
Morphology, gas exchange, and chlorophyll content of longleaf pine seedlings in response to rooting volume, copper root pruning, and nitrogen supply in a container nursery
}

\author{
R. Kasten Dumroese \\ USDA Forest Service, kdumroese@fs.fed.us \\ Shi-Jean Susana Sung \\ USDA Forest Service \\ Jeremiah R. Pinto \\ USDA Forest Service \\ Amy Ross-Davis \\ USDA Forest Service \\ D. Andrew Scott \\ USDA Forest Service
}

Follow this and additional works at: https://digitalcommons.unl.edu/usdafsfacpub

Dumroese, R. Kasten; Sung, Shi-Jean Susana; Pinto, Jeremiah R.; Ross-Davis, Amy; and Scott, D. Andrew, "Morphology, gas exchange, and chlorophyll content of longleaf pine seedlings in response to rooting volume, copper root pruning, and nitrogen supply in a container nursery" (2013). USDA Forest Service / UNL Faculty Publications. 246.

https://digitalcommons.unl.edu/usdafsfacpub/246

This Article is brought to you for free and open access by the U.S. Department of Agriculture: Forest Service -National Agroforestry Center at DigitalCommons@University of Nebraska - Lincoln. It has been accepted for inclusion in USDA Forest Service / UNL Faculty Publications by an authorized administrator of DigitalCommons@University of Nebraska - Lincoln. 


\title{
Morphology, gas exchange, and chlorophyll content of longleaf pine seedlings in response to rooting volume, copper root pruning, and nitrogen supply in a container nursery
}

\author{
R. Kasten Dumroese • Shi-Jean Susana Sung • Jeremiah R. Pinto • \\ Amy Ross-Davis $\cdot$ D. Andrew Scott
}

Received: 11 January 2013/ Accepted: 13 July 2013

(C) Springer Science+Business Media Dordrecht (outside the USA) 2013

This article is a U.S. government work, and is not subject to copyright in the United States.

\begin{abstract}
Few pine species develop a seedling grass stage; this growth phase, characterized by strong, carrot-like taproots and a stem-less nature, poses unique challenges during nursery production. Fertilization levels beyond optimum could result in excessive diameter growth that reduces seedling quality as measured by the root bound index (RBI). We grew longleaf pine (Pinus palustris), a grass stage species, in containers of four different volumes (60-336 ml) either coated with copper oxychloride or left untreated and fertilized at low, medium, or high levels of nitrogen $(\mathrm{N})$. In general, $\mathrm{N}$ concentration of tissues rose as $\mathrm{N}$ rate increased, with larger changes in concentration occurring between low and medium levels than between medium and high levels. $\mathrm{N}$ rate influenced root tissue $\mathrm{N}$ concentration less than it did stems and needles. Subtle needle color differences caused by $\mathrm{N}$ rate were significant, suggesting its potential utility during nursery production. As expected, seedlings grew larger as container volume increased and as $\mathrm{N}$ rate increased. Copper treatment, which we posited could influence the RBI, tended to increase root-collar diameter and tap root biomass and decrease total root volume. Chlorophyll abundance was affected more by $\mathrm{N}$ rate than by container volume or copper treatment, but photosynthesis was affected more by copper treatment than $\mathrm{N}$ rate or container size. Although RBI was $25 \%$ greater for seedlings grown in small containers with high $\mathrm{N}$ rates than those grown in large containers with low $\mathrm{N}$ rates, RBI ranged only from 11 to $15 \%$, well below the critical $27 \%$ threshold.
\end{abstract}

R. K. Dumroese $(\varangle) \cdot$ J. R. Pinto · A. Ross-Davis

USDA Forest Service, Rocky Mountain Research Station, 1221 South Main Street,

Moscow, ID 83843, USA

e-mail: kdumroese@fs.fed.us

S.-J. S. Sung

USDA Forest Service, Southern Research Station, 2500 Shreveport Highway,

Pineville, LA 71360, USA

D. A. Scott

USDA Forest Service, Southern Research Station, 4900 Meridian Street, Normal, AL 35762, USA 
Keywords Pinus palustris $\cdot$ Seedling quality $\cdot$ Morphology $\cdot$ Fertilization · Physiology · Copper oxychloride

\section{Introduction}

Worldwide, only five species of pine have seedlings that develop a "grass stage" (Keeley 2012). Seedlings in the grass stage have a thick, carrot-like taproot, a rudimentary stem, and are characterized by first year needle growth that forms a clump resembling a bunch grass, an evolutionary response to their early development on forest sites that are often oligotrophic and prone to frequent, low-intensity surface fires (Barnett 1999; Keeley 2012). This peculiar seedling morphology poses unique challenges when seedlings are produced for reforestation because these traits render some traditional container seedling quality paradigms (e.g. stem height, sturdiness coefficient) untenable.

For one species with a grass stage, Pinus palustris (longleaf pine) of the southeastern United States, demand for container seedlings has increased dramatically during the past 15 years. Because survival and growth of container longleaf pine often exceeds that of bareroot stock (South et al. 2005), historic concerns by land managers about poorer survival and slower initial growth of longleaf compared to other pine species have dissipated (Barnett 2002), resulting in renewed interest in planting longleaf pine in an attempt to realize the greater economic benefit of its sawtimber compared with other southern pine crops (Kush et al. 2004). Federal incentive programs have further stimulated demand by encouraging restoration of longleaf pine ecosystems (Hainds 2002b); nearly $98 \%$ of the original 36 million ha of longleaf pine forest type have been extirpated, imperiling many terrestrial species dependent on that habitat (Outcalt 2000; Jose et al. 2006). The result is that, from 1996 through 2000, the number of container nurseries nearly doubled and the number of seedlings produced rose $240 \%$ (Hainds 2002a), accounting for $84 \%$ of the 76 million longleaf seedlings grown in the southeastern USA (Dumroese et al. 2009). Many of these container nurseries lacked experienced staff and the result was great variation in longleaf pine seedling quality (Hainds 2004). Subsequently, interim guidelines were proposed (Barnett et al. 2002) and updated (Dumroese et al. 2009) toward improving seedling quality.

For container production of pines, two aspects of seedling quality are of particular concern: optimum mineral nutrient content and root form. Container seedling quality is the nexus between nursery fertilization (Landis 1989) that leads to optimum mineral nutrient content and performance attributes (e.g. improved drought tolerance, cold hardiness, survival, competitive advantage, growth, reduced transplant shock) (van den Driessche 1991; Grossnickle 2000). Although determining optimum fertilization for container seedlings is basic for reforestation (Salifu and Jacobs 2006) and can be determined in the nursery, subsequent seedling performance after outplanting is actually the critical factor (Landis and Dumroese 2006). Jackson et al. (2012) showed that increasing rates of nitrogen (N) applied to longleaf pine seedlings during nursery production reduced time in the grass stage and increased height after outplanting.

Root form of container seedlings is an ongoing topic of discussion. Root system modification has been a research subject since work began on growing seedlings in containers for reforestation (e.g. Saul 1968). This concern reached an apex about 35 years ago when early versions of containers combined with emerging nursery practices were found to 
yield seedlings, especially pine, having poor root egress after outplanting; these seedlings subsequently had poor stability and were prone to toppling (Burdett et al. 1986). Since then, most stability problems have been mitigated by a variety of container modifications, including vertical ribs, air-slits and copper-coatings, in concert with improved seedling culture during nursery production and use of appropriate planting tools (Landis et al. 2010). Specifically for copper-coatings, numerous studies across a wide variety of copper sources, substrates, nursery conditions, and species generally arrive at the same conclusion: coating containers with copper arrests lateral root elongation, preventing roots from deflecting at the container interface and growing basipetally (e.g. Burdett 1978; Burdett and Martin 1982; Ruehle 1985; Dong and Burdett 1986; Struve 1993; Aldrete et al. 2002; Barnett and McGilvray 2002; Sword Sayer et al. 2009). The result is a more fibrous root system and when outplanted, seedlings regenerate lateral roots more uniformly along the length of the root plug. This root egress was also thought to improve a seedling's ability to exploit soil resources (Balisky et al. 1995); that is, the location of new lateral roots originating from plugs modified by copper was thought to be more optimum for acquiring nutrients and water and colonization by mycorrhizal fungi than non-treated seedlings (see Dumroese 2002). Simply growing seedlings too large for, or too long in, the chosen containers may be more important than either stability or resource exploitation. Researchers have warned that growing seedlings too long in their intended containers can affect outplanting performance (Brissette et al. 1991; Salonius et al. 2002). South and Mitchell (2006) found that longleaf pine seedlings with root-collar diameters that exceeded $27 \%$ of the diameter of their containers [i.e., their root bound index (RBI)] had significantly reduced survival.

Thus, optimum seedling quality lies at the intersection of container type and optimum mineral nutrition as a result of fertilization, and can be further influenced by root modification. With a myriad of container types available, with and without root modification elements, discerning an optimum combination of these characters with fertilizer is a stocktype trial. Pinto et al. (2011a) provide guidelines to ensure stocktype trials are done well so that conclusions are sound, biologically and economically. The most common variables confounded in stocktype trials are fertilization and irrigation, so elucidating and using a technique to ensure that each container type receives relatively equal rates of fertilizer would be useful. Using that concept, we examined the interactions of container volume, root pruning via a copper coating applied to the interior of containers, and disparate levels of $\mathrm{N}$ fertilization toward a better understanding of longleaf pine seedling production and outplanting performance. This paper focuses on the seedling production aspects.

\section{Materials and methods}

We grew longleaf pine seedlings at the USDA Forest Service, Rocky Mountain Research Station in Moscow, Idaho USA (46.723179, -117.002753) inside a double polycarbonatecovered, fully-automated greenhouse in a 4 container volume $\times 2$ copper root modification treatment (hereafter copper) $\times 3 \mathrm{~N}$ rate $\times 3$ replicate randomized complete block design. Styroblock ${ }^{\mathrm{TM}}$ containers (no copper) and their equivalent-sized Copperblock ${ }^{\mathrm{TM}}$ containers (interior portions of each cavity, except the ribs, coated with a proprietary amount of copper oxychloride) having volumes ranging from 60 to $336 \mathrm{ml}$ were used (see Table 1 for specifications). In addition to the study reported here, seedlings were also produced simultaneously for a related outplanting study. Therefore, we grew a total of 1,729 seedlings in Styroblock containers and 1,210 in Copperblock containers. Each 
replicate included two to nine Styroblock or Copperblock containers depending on seedling density. On 15 May (Julian date 134; hereafter Julian) we filled containers with a 1:1 (v:v) Sphagnum peat moss:vermiculite medium and sowed two seeds (Louisiana seed source, Louisiana Forest Seed Company, Woodworth, Louisiana USA). Three weeks after sowing (Julian 155), we thinned to a single seedling per cavity.

Fertigations (irrigations with soluble fertilizer added) were designed relative to $\mathrm{N}$ rates used by Jackson et al. (2012) because (1) they determined from a range of $\mathrm{N}$ that $2 \mathrm{mg} \mathrm{N}$ per seedling per week for 20 weeks produced high quality longleaf seedlings in the Ropak ${ }^{\circledR}$ Multi-pot ${ }^{\mathrm{TM}}$ \#3-96 containers (98 ml volume; Stuewe \& Sons, Inc., Tangent, Oregon USA); (2) South and Mitchell (2006) included the same container in their RBI research; (3) and this container is commonly used across the southeastern USA. In addition, Pinto et al. (2011a) describe the benefit of tailoring nursery culture by container type to improve interpretation of container (i.e, stocktype) trials. Therefore, we used the low $\left[0.5 \mathrm{mg} \mathrm{N}\right.$ seedling ${ }^{-1}$ week $^{-1}$ for 20 weeks (hereafter $\mathrm{mg} \mathrm{N}$ )], medium ( $\mathrm{mg} \mathrm{N}$ ), and high (4 mg N) rates of Jackson et al. (2012) but calculated the exact amount of $\mathrm{N}$ based on container volume relative to the Ropak \#3-96 (Table 2). Fertigations began 4 weeks after sowing (Julian 162) and continued once per week for 19 weeks (20 applications total; Julian 295). Frequency of irrigation or fertigation was determined gravimetrically; mass of the empty container and its dry growing medium was measured, and after irrigating and allowing them to drain for $1 \mathrm{~h}$, we determined the field capacity mass of the water within each container. Every time the average mass of the water within a container replicate reached $75 \%$ of the field capacity mass, we irrigated or fertigated seedlings. Once each week, we calculated the amount of fertilizer to add to a sufficient amount of irrigation water in order to apply the appropriate nutrient regime and return the containers to field capacity. Thus, we applied an average of $6,10,13$, and $34 \mathrm{ml}$ of fertigation solution per seedling per week to the $60,95,125$, and $336 \mathrm{ml}$ containers, respectively. We custom blended fertilizers. Our stock fertilization solution was 110, 77, 63, 28, and $20 \mathrm{mg} \mathrm{L}^{-1} \mathrm{P}, \mathrm{K}, \mathrm{S}, \mathrm{Ca}$, and $\mathrm{Mg}$, respectively (Table 3), plus micronutrients (Peters Professional ${ }^{\circledR}$ S.T.E.M. ${ }^{\text {TM }}$, The Scotts Company, Marysville, Ohio USA) applied at $15 \mathrm{mg} \mathrm{L}^{-1}$ and Sprint 330 (chelated Fe; $10 \% \mathrm{Fe}$; Becker Underwood, Inc., Ames, Iowa USA) added at $20 \mathrm{mg} \mathrm{L}^{-1}$. Therefore, increasing fertigation amounts increased the $\mathrm{mg}$ of each nutrient (except $\mathrm{N}$ ) applied but the applied amounts were equal across $\mathrm{N}$ rates within a particular container type. To that we added ammonium nitrate to achieve the desired $\mathrm{N}$ amount per seedling per container size and $\mathrm{N}$ rate. Fertigation solutions were carefully applied by hand to ensure an even distribution of nutrients and minimize leaching. From the end of the fertigation period (22 October; Julian 295) until harvested, seedlings were irrigated when container mass reached $75 \%$.

Table 1 Characteristics of Styroblock ${ }^{\mathrm{TM}}$ and Copperblock ${ }^{\mathrm{TM}}$ containers (Beaver Plastics, Ltd., Acheson, Alberta, Canada)

\begin{tabular}{llllll}
\hline $\begin{array}{l}\text { Designation } \\
\text { (US or Canada) }\end{array}$ & $\begin{array}{l}\text { Cavities } \\
\text { (number) }\end{array}$ & $\begin{array}{l}\text { Volume } \\
(\mathrm{ml})\end{array}$ & $\begin{array}{l}\text { Depth } \\
(\mathrm{cm})\end{array}$ & $\begin{array}{l}\text { Cavity diameter } \\
(\mathrm{cm})\end{array}$ & $\begin{array}{l}\text { Density } \\
(\text { cavities m }\end{array}$ \\
\hline 4A or 313A & 198 & 60 & 13 & 2.8 & 936 \\
6B or 412B & 112 & 95 & 12 & 3.6 & 530 \\
$10 \mathrm{~S}$ or 412A & 77 & 125 & 12 & 4.2 & 364 \\
20 or $615 \mathrm{~A}$ & 45 & 336 & 15 & 5.9 & 213 \\
\hline
\end{tabular}

Copperblock containers are Styroblock containers that have the interior surface of each cavity, except the ribs, coated with a proprietary application of copper oxychloride 
Table 2 Amounts of nitrogen $(\mathrm{N})$ applied per week to each seedling in each container volume using the $\mathrm{N}$ values for the Ropak Multipot \#3-96 (Jackson et al. 2012) as reference points

\begin{tabular}{|c|c|c|c|c|c|c|c|c|}
\hline \multirow{2}{*}{$\begin{array}{l}\text { Designation } \\
\text { (US or Canada) }\end{array}$} & \multirow{2}{*}{$\begin{array}{l}\text { Volume } \\
(\mathrm{ml})\end{array}$} & \multirow{2}{*}{$\begin{array}{l}\text { Relative } \\
\text { volume (\%) }\end{array}$} & \multicolumn{3}{|c|}{ Relative $\mathrm{N}$ applied per week (mg) } & \multicolumn{3}{|c|}{ Total $\mathrm{N}$ applied (mg) } \\
\hline & & & 0.5 & 2.0 & 4.0 & Low & Medium & High \\
\hline Ropak \#3-96 & 98 & 1.0 & 0.5 & 2.0 & 4.0 & 10 & 40 & 80 \\
\hline $4 \mathrm{~A}$ or $313 \mathrm{~A}$ & 60 & 0.6 & 0.3 & 1.2 & 2.4 & 6 & 24 & 49 \\
\hline $6 \mathrm{~B}$ or $412 \mathrm{~B}$ & 95 & 1.0 & 0.5 & 1.9 & 3.9 & 10 & 39 & 78 \\
\hline $10 \mathrm{~S}$ or $412 \mathrm{~A}$ & 125 & 1.3 & 0.6 & 2.6 & 5.1 & 13 & 51 & 102 \\
\hline 20 or $615 \mathrm{~A}$ & 336 & 3.4 & 1.7 & 6.9 & 13.7 & 34 & 137 & 274 \\
\hline
\end{tabular}

Table 3 Fertigation stock solution

\begin{tabular}{llllllll}
\hline Fertilizer & \multicolumn{2}{l}{ Concentration $\left(\mathrm{mg} \mathrm{L}^{-1}\right)$} & & & \\
\cline { 2 - 6 } & $\mathrm{NO}_{3}$ & $\mathrm{NH}_{4}$ & $\mathrm{P}$ & $\mathrm{K}$ & $\mathrm{Ca}$ & $\mathrm{Mg}$ & $\mathrm{S}$ \\
\hline $\mathrm{H}_{3} \mathrm{PO}_{4}(75 \%)$ & & 60 & & & \\
$\mathrm{Ca}\left(\mathrm{NO}_{3}\right)_{2}$ & 25 & & 50 & 57 & & & \\
$\mathrm{~K}_{2} \mathrm{O}+\mathrm{P}_{2} \mathrm{O}_{5}$ & & & & & 20 & 26 \\
$\mathrm{MgSO}_{4}$ & & & & & & 8 \\
$\mathrm{~K}_{2} \mathrm{SO}_{4}$ & & 25 & & & & & 29 \\
$\left(\mathrm{NH}_{4}\right)_{2} \mathrm{SO}_{4}$ & 25 & 25 & 110 & 77 & 28 & 20 & 63 \\
Total & & & & & & & \\
\hline
\end{tabular}

Near the end of the fertigation schedule (15 October; Julian 288), we measured net photosynthetic assimilation $(A)$ on 2 seedlings from each container volume $(4) \times$ copper coating $(2) \times \mathrm{N}$ rate $(3)$ combination (48 seedlings total). We used a LI-6400 infrared gas analyzer equipped with a blue/red LED light source and $\mathrm{CO}_{2}$ injector (Li-Cor, Inc., Lincoln, Nebraska USA). Measurements were conducted between 10:00 and 14:00 where ambient photosynthetically active radiation (PAR) exceeded $1,500 \mu \mathrm{mol} \mathrm{m}^{-2} \mathrm{~s}^{-1}$. For each measurement, two secondary needle fascicles were placed in the chamber while still attached to the stem. The internal chamber environment was set at $1,400 \mu \mathrm{mol} \mathrm{m}{ }^{-2} \mathrm{~s}^{-1}$ PAR, $24( \pm 0.5){ }^{\circ} \mathrm{C}, 400 \mu \mathrm{mol} \mathrm{m} \mathrm{m}^{-2} \mathrm{~s}^{-1} \mathrm{CO}_{2}, 40-55 \%$ relative humidity, and an air flow rate of $400 \mu \mathrm{mol} \mathrm{s}^{-1}$. Following enclosure in the chamber, we logged data when a leaf reached a steady-state value (coefficient of variations of $\mathrm{CO}_{2}$ and water within the chamber was $<0.25 \%$ ). Values for $A$ were then corrected for leaf area, which we calculated using the methods of Svenson and Davies (1992) as adapted by Pinto et al. (2012).

On 4 December (Julian 338), we randomly sampled 10 seedlings from each container size $(4) \times$ copper coating $(2) \times \mathrm{N}$ rate $(3) \times$ replication $(3)$ combination $(720$ seedlings total). We measured longest needle length, root volume (Burdett 1979), shoot and root biomass after drying at $60{ }^{\circ} \mathrm{C}$ to constant mass $(>72 \mathrm{~h}$ ), and Munsell color (hue, value, and chroma; ASTM 1989); ColorAccuracy.com, North Brunswick, New Jersey USA) at the midpoint of fascicular needles. After grinding to fine powder, $\mathrm{N}$ concentration of needles, stems (acropetal the cotyledon scar), and roots (tissues basipetal the cotyledon scar) was determined using a LECO CNS 2000 elemental analyzer (LECO Corp., St. Joseph, 
Michigan USA). Foliar and root macro- and micro-nutrient concentrations by each container volume $(4) \times \mathrm{N}$ rate $(3) \times$ plant part $(2) \times$ replication (3) combination $(72 \mathrm{sam}-$ ples) were evaluated by the JR Peters Testing Laboratory (Allentown, Pennsylvania USA). Lost samples prevented further analysis of seedlings grown with the copper coating.

Root-collar diameter (RCD) is perhaps the most critical morphological feature of longleaf pine seedlings (see Jackson et al. 2012) and can be measured non-destructively. Therefore, we measured RCD of 45 copper-treated and 90 control seedlings per replicate (135 and 270 seedlings total) destined for a subsequent outplanting experiment. We calculated $\mathrm{RBI}_{\text {dia }}$ (hereafter RBI) defined by South and Mitchell (2006): RBI equals seedling RCD (mm) divided by container diameter ( $\mathrm{mm}$ ). We collected 6 to 8 -cm-long needle sections, measured surface area using the displacement method of Johnson (1984), and cut the needle sections into $0.2-0.3 \mathrm{~cm}$ segments (tissue was not ground). Chlorophyll $a(\mathrm{Chl} a)$ and chlorophyll $b$ (Chl $b)$ was extracted with N,N'-dimethylformamide (DMF) (Moran and Porath 1980). Culture tubes containing DMF and needle segments were refrigerated until the segments became almost beige white. Absorbance of the DMF extract was read at 664 and $647 \mathrm{~nm}$ by a DU-70 spectrophotometer (BeckmanCoulter Inc., Fullerton, California USA). We calculated $\mathrm{Chl} a$ and $\mathrm{Chl} b$ contents using the simultaneous equations of Porra et al. (1989).

\section{Statistical analysis}

Analysis of variance (ANOVA) was used to examine the effects of container type, $\mathrm{N}$ rate, and copper treatment on root-collar diameter $(\mathrm{mm})$, longest needle length $(\mathrm{cm})$, total shoot dry biomass $(\mathrm{g})$, total root dry biomass $(\mathrm{g})$, tap root dry biomass $(\mathrm{g})$, total root volume $(\mathrm{ml})$, tap root volume $(\mathrm{ml})$, ratio of shoot dry biomass $(\mathrm{g})$ to root dry biomass $(\mathrm{g})$, net photosynthetic assimilation $\left(\mu \mathrm{mol} \mathrm{m} \mathrm{m}^{-2} \mathrm{~s}^{-1}\right.$ ), conductance $\left(\mathrm{mol} \mathrm{H}_{2} \mathrm{O} \mathrm{m}^{-2} \mathrm{~s}^{-1}\right)$, transpiration $\left(\mathrm{mmol} \mathrm{H} \mathrm{O} \mathrm{m}^{-2} \mathrm{~s}^{-1}\right.$ ), water-use efficiency $\left(\mu \mathrm{mol} \mathrm{CO} \mathrm{C}^{-2} \mathrm{~s}^{-1} / \mathrm{mmol} \mathrm{H}_{2} \mathrm{O} \mathrm{m} \mathrm{m}^{-2} \mathrm{~s}^{-1}\right.$ ), and chlorophyll ( $a, b$, and $\left.a+b\left[\mu \mathrm{g} \mathrm{cm}^{-2}\right]\right)$ using SAS PROC GLIMMIX ( $\left.\alpha=0.05\right)$. ANOVA was also used to examine the effects of container type and fertilizer rate on $\mathrm{N}$ concentration $\left(\mathrm{g} \mathrm{kg}^{-1}\right)$ of roots, needles, and stems, and Munsell value/chroma of needles. Comparisons within main effects and interactions (pairwise contrasts) were analyzed using Tukey's tests.

\section{Results}

Nutrient concentrations, chlorophyll content, and needle color

Across treatments, concentrations of macronutrients $(\mathrm{P}, \mathrm{K}, \mathrm{Ca}$, and $\mathrm{Mg}$ ) and micronutrients ( $\mathrm{B}, \mathrm{Cu}, \mathrm{Fe}, \mathrm{Mn}, \mathrm{Mo}$, and $\mathrm{Zn}$ ) were within the standard ranges (data not shown) reported by Landis et al. (1989) with one exception. Foliar Mo values were below the recommended $0.25 \mathrm{mg} \mathrm{kg}^{-1}$ level at the highest $\mathrm{N}$ rate regardless of container volume, and at the medium $\mathrm{N}$ rate for the two smallest containers $(60$ and $95 \mathrm{ml}$; data not shown); the average value for these treatments was $0.14 \mathrm{mg} \mathrm{kg}^{-1}$.

Nitrogen rate and container volume significantly affected tissue $\mathrm{N}$ concentrations (Table 4). Increasing $\mathrm{N}$ rate from low to medium yielded 129 and $62 \%$ greater $\mathrm{N}$ concentrations in roots and needles, respectively. Increasing $\mathrm{N}$ rate from medium to high was less dramatic, with increases of 49 and $30 \%$ noted in the roots and needles, respectively. As $\mathrm{N}$ rate increased, more variation in needle $\mathrm{N}$ concentration was observed (Fig. 1). When $\mathrm{N}$ concentrations resulting from each $\mathrm{N}$ rate were plotted against container volume (data not shown), linear regressions revealed that as $\mathrm{N}$ rate increased from 0.5 to 2 to $4, \mathrm{R}^{2}$ values 
decreased from 0.79 to 0.54 to 0.20 , respectively. For stem $\mathrm{N}$ concentration, we detected a significant interaction between container volume and $\mathrm{N}$ rate: seedlings did not differ among container volumes at the low $\mathrm{N}$ rate, but at the medium $\mathrm{N}$ rate stem $\mathrm{N}$ concentration was greater in $336 \mathrm{ml}$ containers compared to all other volumes $(p \leq 0.0213)$ and at the high $\mathrm{N}$ rate stem $\mathrm{N}$ concentration was greater in 336 and $125 \mathrm{ml}$ containers compared to those grown in 60 and $95 \mathrm{ml}$ containers $(p \leq 0.0231)$. In general, seedlings grown in containers having $\leq 125 \mathrm{ml}$ volume had about $12.5,21.5$, and $13.2 \mathrm{~g} \mathrm{~kg}^{-1} \mathrm{~N}$ in their roots, stems, and needles, respectively, but seedlings in the $336 \mathrm{ml}$ containers had 18 , 28 , and $15 \%$ greater $\mathrm{N}$ concentrations in their roots, stems, and needles than seedlings in those smaller containers.

Table $4 P$ values for the effects of independent variables (container volume, nitrogen rate, and presence or absence of copper oxychloride) and their two- and three-way interactions on the 20 dependent parameters assessed using an analysis of variance and an alpha level of 0.05

\begin{tabular}{|c|c|c|c|c|c|c|c|}
\hline & $\begin{array}{l}\text { Container } \\
\text { (C) }\end{array}$ & $\begin{array}{l}\text { Nitrogen } \\
(\mathrm{N})\end{array}$ & $\mathrm{C} \times \mathrm{N}$ & $\begin{array}{l}\text { Copper } \\
(\mathrm{Cu})\end{array}$ & $\mathrm{C} \times \mathrm{Cu}$ & $\mathrm{N} \times \mathrm{Cu}$ & $\mathrm{C} \times \mathrm{N} \times \mathrm{Cu}$ \\
\hline \multicolumn{8}{|l|}{$\mathrm{N}$ concentration } \\
\hline Roots & 0.0096 & $<0.0001$ & 0.0754 & - & - & - & - \\
\hline Shoots & $<0.0001$ & $<0.0001$ & 0.0017 & - & - & - & - \\
\hline Needles & $<0.0001$ & $<0.0001$ & 0.0900 & - & - & - & - \\
\hline \multicolumn{8}{|l|}{ Munsell color } \\
\hline Value & $<0.0001$ & $<0.0001$ & 0.8960 & - & - & - & - \\
\hline Chroma & 0.0002 & $<0.0001$ & 0.0105 & - & - & - & - \\
\hline $\begin{array}{c}\text { Root-collar } \\
\text { diameter }\end{array}$ & $<0.0001$ & $<0.0001$ & $<0.0001$ & $<0.0001$ & 0.8063 & 0.5640 & 0.0029 \\
\hline $\begin{array}{l}\text { Longest needle } \\
\text { length }\end{array}$ & $<0.0001$ & $<0.0001$ & 0.3806 & 0.9583 & 0.6707 & 0.5883 & 0.8386 \\
\hline \multicolumn{8}{|l|}{ Biomass } \\
\hline Shoot & $<0.0001$ & $<0.0001$ & $<0.0001$ & 0.8917 & 0.0558 & 0.8369 & 0.0188 \\
\hline Tap root & $<0.0001$ & 0.5774 & 0.7530 & 0.0140 & 0.3699 & 0.7156 & 0.2601 \\
\hline Total root & $<0.0001$ & 0.1033 & 0.9393 & 0.8231 & 0.0835 & 0.5632 & 0.1355 \\
\hline Shoot-to-root ratio & 0.0002 & $<0.0001$ & 0.0314 & 0.3120 & 0.2283 & 0.2597 & 0.0983 \\
\hline \multicolumn{8}{|l|}{ Volume } \\
\hline Tap root & $<0.0001$ & 0.0238 & 0.8893 & 0.1336 & 0.7939 & 0.6618 & 0.3067 \\
\hline Total root & $<0.0001$ & 0.7263 & 0.4415 & 0.0001 & 0.0021 & 0.0427 & 0.0010 \\
\hline \multicolumn{8}{|l|}{ Chlorophyll } \\
\hline$a$ & 0.0003 & $<0.0001$ & 0.3315 & 0.4026 & 0.0143 & 0.6021 & 0.0366 \\
\hline$b$ & 0.0006 & $<0.0001$ & 0.2449 & 0.7089 & 0.0042 & 0.9007 & 0.0251 \\
\hline$a+b$ & 0.0004 & $<0.0001$ & 0.3131 & 0.4658 & 0.0106 & 0.6790 & 0.0827 \\
\hline Photosynthesis $(A)$ & 0.0021 & 0.4047 & 0.1117 & 0.0455 & 0.8324 & 0.0212 & 0.0294 \\
\hline Conductance $\left(g_{s}\right)$ & 0.0365 & 0.9935 & 0.4886 & 0.0196 & 0.7978 & 0.0513 & 0.0314 \\
\hline Transpiration $(E)$ & 0.0191 & 0.9847 & 0.4338 & 0.0218 & 0.6992 & 0.0330 & 0.0168 \\
\hline $\begin{array}{l}\text { Water use } \\
\text { efficiency }\end{array}$ & 0.0003 & 0.4010 & 0.0059 & 0.6585 & 0.1068 & 0.0002 & $<0.0001$ \\
\hline
\end{tabular}

Copper data for $\mathrm{N}$ concentration and Munsell color was unavailable for analysis 


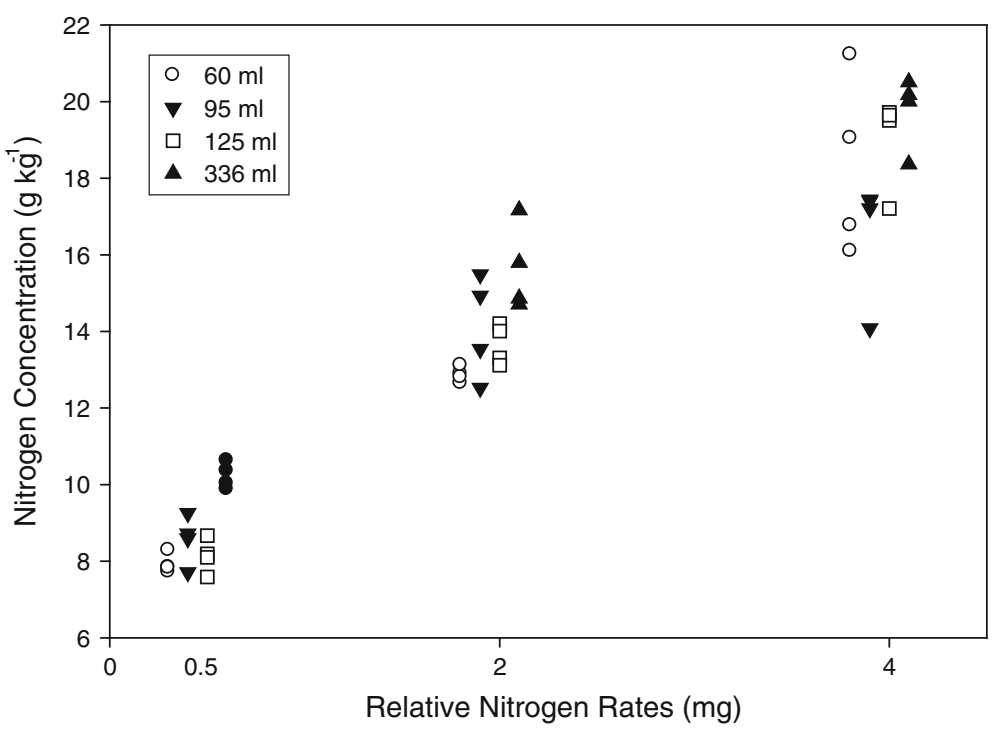

Fig. 1 Nitrogen concentration $\left(\mathrm{g} \mathrm{kg}^{-1}\right)$ of needles on seedlings for each container volume $(60,95,125$, or $336 \mathrm{ml})$ and relative nitrogen $(\mathrm{N})$ rate $(0.5,2$, or $4 \mathrm{mg})$. Values at each $\mathrm{N}$ rate are staggered to improve clarity among container volumes

Trends were similar across measures of chlorophyll (Table 4). Using Chl $a\left(\mu \mathrm{g} \mathrm{cm}^{-2}\right)$ as the example, the significant container $\times \mathrm{N}$ rate $\times$ copper treatment interaction indicated that Chl $a$ concentration was higher in seedlings grown in $336 \mathrm{ml}$ containers coated with copper and given the highest $\mathrm{N}$ rate compared to seedlings in $60 \mathrm{ml}$ containers with the same treatments $(p=0.0005)$. Further, chlorophyll concentration was generally higher among seedlings receiving the highest $\mathrm{N}$ rate compared to the lowest when grown in copper-coated containers of volumes $\geq 95 \mathrm{ml}(p \leq 0.0068)$.

Regardless of treatment, all but 3 of the 240 measured seedlings shared the same Munsell hue: 7.5 greenish Green-Yellow (37.5). Overall, value/chroma ranged from $3 / 4$ to $6 / 10$. Nearly $89 \%$ (213 of 240) of the seedlings were either $4 / 6(53 \% ; 127$ of 240$)$ or $5 / 6$ (36\%; 86 of 240). Of the $4 / 6$ seedlings, $88 \%$ (112 of 127) had received either medium (43\%; 55 of 127$)$ or high $(45 \% ; 57$ of 127$) \mathrm{N}$ rates, whereas of the $5 / 6$ seedlings, $95 \%$ ( 82 of 86) had received low (67 \%; 58 of 86) or medium (28\%; 24 of 86) $\mathrm{N}$ rates. In other words, seedlings receiving medium to high $\mathrm{N}$ were darker (lower value) than those receiving low to medium $\mathrm{N}$, but with similar chroma (i.e., color strength or departure from neutral toward pure color, in this case, Yellow-Green). Seedlings grown in $336 \mathrm{ml}$ containers were significantly darker (lower value) than those grown in all other container volumes; value also decreased as relative $\mathrm{N}$ rate increased (Table 4). For chroma, container volume interacted significantly with $\mathrm{N}$ rate such that chroma was lower for seedlings grown in $336 \mathrm{ml}$ containers compared to those grown in 95 and $60 \mathrm{ml}$ containers only at the highest $\mathrm{N}$ rate $(p \leq 0.0231)$. Furthermore, chroma was lower in seedlings given the highest $\mathrm{N}$ rate only when grown in 60 or $336 \mathrm{ml}$ container volumes $(p \leq 0.0038)$.

\section{Photosynthesis}

Container volume, $\mathrm{N}$ rate, and copper treatment interacted to affect photosynthesis $(A)$, conductance $\left(g_{s}\right)$, transpiration $(E)$, and water-use efficiency (WUE) (Table 4). When 
seedlings were exposed to copper and provided the lowest $\mathrm{N}$ rate, those in $336 \mathrm{ml}$ containers had higher $A$ and $E$ than those grown in $60 \mathrm{ml}$ containers ( $p=0.0133$ and 0.0205 for $A$ and $E$, respectively). For $A, g_{s}$, and $E$, although copper treatment was significant, no pairwise comparisons showed a copper treatment effect $(p \geq 0.7694,0.6086$, and 0.5624 , for $A, g_{s}$, and $E$ respectively) and for $g_{s}$ the same was true for a container effect ( $p \geq 0.0571$ ). Seedlings grown in $60 \mathrm{ml}$ containers had higher $W U E$ than seedlings grown in all other container volumes when copper treated and given the lowest $\mathrm{N}$ rate $(p \leq 0.0002)$.

\section{Seedling morphology}

Container volume, $\mathrm{N}$ rate, and copper treatment interacted to affect RCD (Table 4; Fig. 2). RCD was greater among seedlings grown in $336 \mathrm{ml}$ containers relative to all other container volumes across $\mathrm{N}$ rates and copper treatments $(p \leq 0.0002)$, with no difference in RCD among seedlings grown in 95 and $125 \mathrm{ml}$ containers $(p \geq 0.1592)$. In the $336 \mathrm{ml}$ containers, seedling RCD differed between the lowest and medium $\mathrm{N}$ rates only when containers lacked the copper coating ( $p=0.0328$ ) whereas RCD of seedlings in the $60 \mathrm{ml}$ containers did not differ among $\mathrm{N}$ rates regardless of copper treatment $(p \geq 0.5536)$. For intermediate container volumes, RCDs were generally greater for the medium and high $\mathrm{N}$ rates relative to the low $\mathrm{N}$ rate regardless of copper treatment $(p \leq 0.0137)$. No seedlings exceeded the $27 \%$ RBI threshold, with a range of averages from 11.8 to $14.1 \%$ (Fig. 2). The length of the longest needle was significantly affected by container and by $\mathrm{N}$; needles were longer when seedlings received medium or high $\mathrm{N}$ rates, regardless of container volume, or when grown in $336 \mathrm{ml}$ containers, regardless of $\mathrm{N}$ rate.

Container volume, $\mathrm{N}$ rate, and copper treatment interacted to affect shoot biomass and total root volume (Table 4). Shoot biomass in the $336 \mathrm{ml}$ containers was greater than all other container volumes regardless of $\mathrm{N}$ rate or copper treatment $(p \leq 0.0173)$; the $60 \mathrm{ml}$

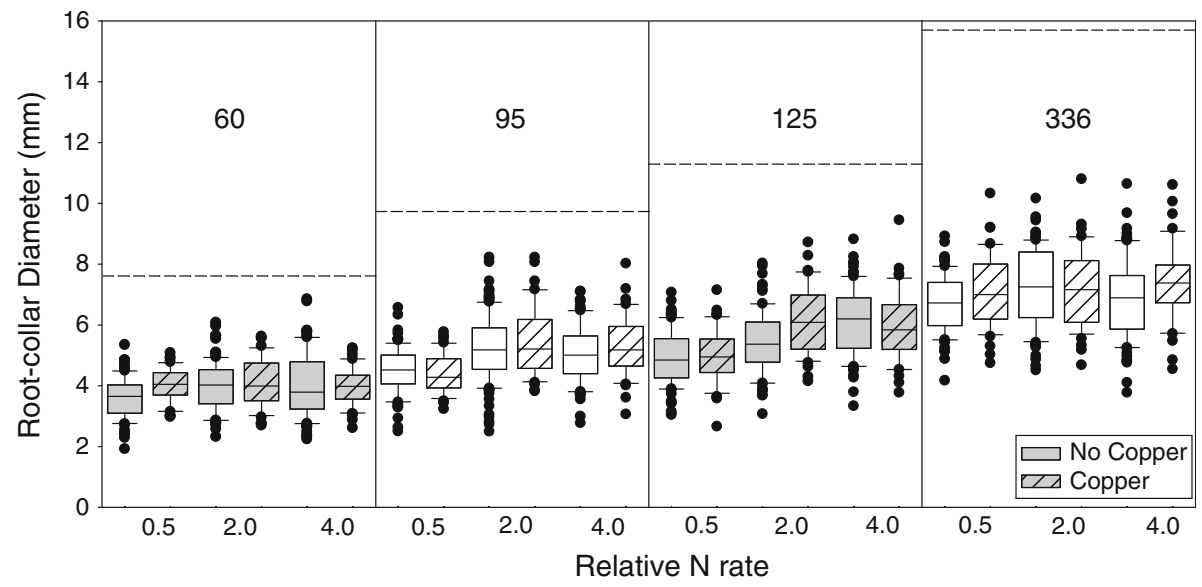

Fig. 2 Box-plots for root-collar diameter data (box represents the 25th and 75th percentiles, horizontal line within the box shows the median, fences are at the 10th and 90th percentiles, and filled circles indicate points outside these percentiles, some of which could potentially be outliers) for each container volume (60, 95, 125, or $336 \mathrm{ml}$ ), copper treatment (none = no diagonal fills; copper $=$ diagonal fills), and relative nitrogen $(\mathrm{N})$ rate $(0.5,2$, or 4$)$. The horizontal dashed line within each container volume represents the rootcollar diameter at which seedlings would reach the $27 \%$ RBI value of South and Mitchell (2006) 
Table 5 Means and standard errors (s.e.) for tap root and total root biomass and tap root volume by container volume, nitrogen rate, and copper treatments
Different letters within each independent variable and seedling parameter indicate a significant difference at alpha $=0.05$

\begin{tabular}{cllll}
\hline & & $\begin{array}{l}\text { Tap root } \\
\text { biomass }(\mathrm{g})\end{array}$ & $\begin{array}{l}\text { Total root } \\
\text { biomass }(\mathrm{g})\end{array}$ & $\begin{array}{l}\text { Tap root } \\
\text { volume }(\mathrm{ml})\end{array}$ \\
\hline $\begin{array}{c}\text { Container } \\
\text { volume }\end{array}$ & 60 & $0.26 \mathrm{a}$ & $0.37 \mathrm{a}$ & $0.74 \mathrm{a}$ \\
& 95 & $0.44 \mathrm{~b}$ & $0.62 \mathrm{~b}$ & $1.46 \mathrm{~b}$ \\
& 125 & $0.46 \mathrm{~b}$ & $0.66 \mathrm{~b}$ & $1.38 \mathrm{~b}$ \\
& 336 & $0.74 \mathrm{c}$ & $1.08 \mathrm{c}$ & $2.47 \mathrm{c}$ \\
Nitrogen & Low & 0.47 & 0.03 & 0.09 \\
rate & Medium & 0.50 & 0.69 & $1.38 \mathrm{a}$ \\
& High & 0.46 & 0.72 & $1.67 \mathrm{~b}$ \\
& s.e & 0.02 & 0.63 & $1.49 \mathrm{ab}$ \\
Copper & No & $0.44 \mathrm{a}$ & 0.03 & 0.08 \\
& Yes & $0.51 \mathrm{~b}$ & 0.68 & 1.45 \\
& s.e. & 0.02 & 0.02 & 0.06 \\
\hline
\end{tabular}

containers also produced seedlings with lower shoot dry biomass than the intermediate container volumes when coated with copper at the high $\mathrm{N}$ rate $(p \leq 0.0073)$ or when compared to uncoated $125 \mathrm{ml}$ containers at the medium $\mathrm{N}$ rate $(p=0.0003)$. Shoot biomass was lower among seedlings receiving the low $\mathrm{N}$ rate when grown in 125 and $336 \mathrm{ml}$ containers regardless of copper treatment ( $p \leq 0.0363$ ), whereas this was only observed for the $95 \mathrm{ml}$ containers when coated with copper $(p=0.0002)$. Total root volume was greater for seedlings grown in the $336 \mathrm{ml}$ containers across all $\mathrm{N}$ rate and copper treatment combinations $(p \leq 0.0001)$, except when compared to the copper-coated $125 \mathrm{ml}$ containers at the high $\mathrm{N}$ rate $(p=0.2930)$. Copper treatment was significant only for seedlings in $336 \mathrm{ml}$ containers at the highest $\mathrm{N}$ rate $(p<0.0001)$.

Tap root biomass, total root biomass, and tap root volume were unaffected by any treatment interactions (Table 4). Similar effects of container volume were observed for these variables (Table 5): roots were largest for seedlings grown in $336 \mathrm{ml}$ containers, followed by those grown in 95 and $125 \mathrm{ml}$ containers, with those grown in $60 \mathrm{ml}$ containers producing the smallest roots, regardless of $\mathrm{N}$ rate or copper treatment. Tap root biomass was further affected by copper treatment such that biomass was greater for those seedlings grown in copper-coated containers. Tap root volume was also affected by $\mathrm{N}$ rate such that seedlings receiving the medium $\mathrm{N}$ rate yielded significantly larger tap roots as measured by volume than those receiving the lowest $\mathrm{N}$ rate.

Container volume and $\mathrm{N}$ rate interacted to affect shoot-to-root ratio (S:R) (Table 4). S:R was greater for seedlings grown in $336 \mathrm{ml}$ containers than 95 and $125 \mathrm{ml}$ containers when given the highest $\mathrm{N}$ rate $(p \leq 0.0010)$. Across all container volumes, $\mathrm{S}: \mathrm{R}$ was greater for seedlings receiving the highest $\mathrm{N}$ rate relative to the lowest rate $(p \leq 0.0191)$.

\section{Discussion}

In an attempt to avoid confounding irrigation and fertilization across disparate container sizes as suggested by Pinto et al. (2011a), we employed the same $\mathrm{N}$ rates (mg $\mathrm{N}$ per seedling per $\mathrm{ml}$ of container volume) and same volumetric rates for scheduling irrigation as those used for Ropak \#3-96 containers by Jackson et al. (2012). Our results are somewhat mixed. On one hand, using a relative $\mathrm{N}$ rate yielded similar $\mathrm{N}$ concentrations in roots 
$( \pm 0.07 \%)$, stems $( \pm 0.29 \%)$, and needles $( \pm 0.06 \%)$ for container sizes within $50 \%$ of the Ropak used by Jackson et al. (2012). Moreover, our lack of a significant interaction between container size and $\mathrm{N}$ rate for root and needle $\mathrm{N}$ concentration suggests that the technique we used has merit for transferring optimum $\mathrm{N}$ rates across differing container volumes; others have obtained similar results when applying a constant $\mathrm{N}$ rate relative to container volume (Aphalo and Rikala 2003; Pinto et al. 2011b; Oliet et al. 2012). On the other hand, the $\mathrm{N}$ concentrations of longleaf pine tissues for container sizes within $50 \%$ of the Ropak used by Jackson et al. (2012) were significantly less than those observed in the largest containers $(336 \mathrm{ml})$ that had three times the Ropak volume. This is contrary to work by Oliet et al. (2012) who found no differences in nutrient concentrations of shrub seedlings grown with containers that differed in volume by $700 \mathrm{ml}$ but had similar media nutrient concentrations. It is not clear why our results are different, but it could be related to differences in morphology between a Mediterranean shrub and a conifer in the grass stage and/or that longleaf pine seedlings in the largest container had absorbed the $\mathrm{N}$ but had insufficient time to convert that resource into new tissue.

As expected, increasing the amount of $\mathrm{N}$ applied to seedlings increased seedling size, and as observed by Jackson et al. (2012), we also noted a greater increase in RCD and needle length when $\mathrm{N}$ rate moved from low to medium than moving from medium to high. Our results for shoot growth and root growth also concur with Jackson et al. (2012) in that shoot biomass was significantly greater with each increase in $\mathrm{N}$ rate whereas total root biomass was constant across $\mathrm{N}$ rates, suggesting greater plasticity in the shoot response to $\mathrm{N}$ fertilization. In our study, this was also reflected in more variation in needle $\mathrm{N}$ concentration as $\mathrm{N}$ rate increased (Fig. 1). As a result, $\mathrm{S}: \mathrm{R}$ increased significantly with additional $\mathrm{N}$, with the $4 \mathrm{mg} \mathrm{N}$ rate yielding a $\mathrm{S}: \mathrm{R}$ of 3.7 , much greater than that reported by Sword Sayer et al. (2009) (2.8) and Jackson et al. (2012) (0.9).

In our study seedlings followed the accepted paradigm that larger containers yield larger seedlings (Landis et al. 1990), which has been shown for longleaf pine as well (Sword Sayer et al. 2009). We found that seedlings grown in the smallest containers $(60 \mathrm{ml})$ were significantly smaller than those grown in containers having volume $\geq 95 \mathrm{ml}$. Moreover, seedlings grown in the smallest container showed significantly increased $A$ (despite similar levels of Chl $a$ and $b, g_{s}$, and $E$ ) than those grown in the next larger size (95 $\left.\mathrm{ml}\right)$; subsequently the smallest container had the highest WUE, suggesting that water was limiting in those containers even though irrigation was initiated at the same threshold. Under similar irrigation conditions and with similar containers to this study, Davis et al. (2011) found that longleaf pine seedlings grown in $60 \mathrm{ml}$ containers and tested in December were less cold hardy than those produced in $125 \mathrm{ml}$ containers. Given that cold hardiness is considered a surrogate for quantifying overall seedling stress resistance (Ritchie et al. 2010), these smallest containers yield seedlings of lesser quality. This supports the original guidelines for growing longleaf pine seedlings in containers, where Barnett et al. (2002) recommended, based on several earlier studies (see Dumroese et al. 2009) that container volume be $\geq 90 \mathrm{ml}$. This also concurs with Sung et al. (2010) who found that, after 2 years in the field, longleaf pine seedlings grown in $60 \mathrm{ml}$ containers had significantly less survival, height, and exit from the grass stage than those grown in $95 \mathrm{ml}$ containers.

Different effects of copper on the growth of pines have been noted. Because of the various potential combinations of containers, media, copper forms, etc., it is not surprising that studies involving copper root pruning, often with the same species, yield slightly different to very different results. For example, cupric carbonate had little effect on shoot and root biomass of Pinus ponderosa (Wenny and Woollen 1989) whereas copper 
hydroxide decreased root biomass and increased shoot biomass (Dumroese and Wenny 1997). For Pinus montezumae, which also forms a grass stage, copper hydroxide yielded more shoot and root biomass than the control (Aldrete et al. 2002). Conversely, Barnett and McGilvray (2002) report increases in longleaf pine shoot biomass without any increase in root biomass; they had similar results with copper oxychloride. However, Sword Sayer et al. (2009) report increases in tap root biomass and shoot and root dry weights for seedlings exposed to copper oxychloride. In this study, we also observed an increase in tap root biomass but no changes to shoot or total root biomass with exposure to copper oxychloride. We noted that total root volume was decreased approximately $13 \%$ by exposure to copper oxychloride in this study, similar to work with $P$. ponderosa (Dumroese and Wenny 1997). This may be because copper-treated seedlings lack the thicker, downward deflected lateral roots at the container-medium interface commonly observed with non-copper-treated seedlings; these roots are instead replaced with shorter, finer, second-order laterals (as observed in this study).

Why are various responses of copper observed with longleaf pine seedling morphology? Part of the answer may be genetics as Sword Sayer et al. (2005) noted differences in root development among seed origin. It is most likely that Barnett and McGilvray (2002), Sword Sayer et al. (2009), and this study used different seed sources. The quality of the fertilizer solutions could be involved: Lambert and Weidensaul (1982) found that for Pinus strobus, levels of copper in commercial fertilizers were often below what was required for optimum growth; they cite Fiedler et al. (1973) who indicate that pines are most sensitive to copper deficiencies. Thus, no effect on growth might be observed when copper levels are sufficient, whereas an improvement in growth might be observed when the copper coatings provide additional copper when fertilizer dosages are insufficient. Dunn et al. (1997) found that copper concentrations in foliage of tree seedlings root pruned with copper was elevated compared to control seedlings but still within the acceptable range for growth. Moreover, Burdett and Martin (1982) speculate that the content of divalent cations, particularly $\mathrm{Ca}$, may decrease the uptake of copper and reduce the efficacy of root pruning. Modifying the fertilizer regimes can mitigate this problem (Landis and van Steenis 2000; van Steenis 1994). Because copper oxychloride is more soluble than cupric carbonate, it is likely that chemistry of the medium, nutrient availability, and subsequent seedling growth would be impacted more by this form of copper (Dumroese et al. 2002).

When comparing across container volume for all rates of $\mathrm{N}$ and all copper treatments, the smallest containers yielded about $20 \%$ greater RBI than the largest containers (Fig. 2). Seedlings grown in the smallest containers with the highest rate of $\mathrm{N}(4 \mathrm{mg} \mathrm{N})$ had a RBI $25 \%$ greater than those grown in the largest container with the lowest $\mathrm{N}$ rate $(0.5 \mathrm{mg} \mathrm{N})$. Our intent with the small containers and high $\mathrm{N}$ rates was, however, to produce seedlings exceeding the critical RBI value of $27 \%$ described by South and Mitchell (2006). Instead, RBI values in our study ranged only from 11.1 to $15.2 \%$, well below the critical value. Our range of values is consistent with Barnett (1984, 1989), Dumroese et al. (2005), Sword Sayer et al. (2011), and Jackson et al. (2012) who report ranges of 11.3, 10.8-16.6, 11.6-16.5, 8-13, and 5.8-28\%, respectfully, for container seedlings $<1$ year old. South et al. (2001) reported that operationally grown longleaf seedlings had a RBI of $16.3-18.3 \%$ at outplanting; 8 mo later the seedlings RCD had increased to just $23 \%$ of their original container diameter. Those results, along with Jackson et al. (2012) and this study showing little increase in RCD once $\mathrm{N}$ reaches a critical value in the nursery, indicate that the $27 \%$ RBI threshold is difficult to reach when seedlings are properly grown $\leq 1$ year in their containers. Holding stock over for additional time, however, may provide seedlings sufficient time to reach and surpass the critical RBI value (e.g. Salonius et al. 
2002), which is why holding stock in the same container past its scheduled outplanting date is discouraged (Landis 2012).

Although qualitative assessment of needle color is a tenuous way to infer seedling quality, Linder (1980) and Heiskanen (2005) found that foliar $\mathrm{N}$ concentration and levels of Chl $a+b$ correlated with quantified foliar color. Despite this, foliar color within the range of green is generally an unreliable predictor of outplanting performance because it is affected by other biotic and abiotic factors (Linder 1980). As Heiskanen (2005) concludes, it may, however, have utility in determining the need for fertilization. In our study, quantitative assessment of needle color indicated that $90 \%$ of the seedlings receiving medium or high $\mathrm{N}$ rates, regardless of container volume, were classified as 7.5GY 4/6. Conversely, two-thirds of the seedlings receiving low $\mathrm{N}$ rate were classified as 7.5GY 5/6. This suggests that including standard Munsell colors as part of a target seedling definition may provide nursery managers with an additional tool in determining fertilization schedules.

Although neither South et al. (2005) nor Sung et al. (2010) noted any short-term benefit, in terms of survival or growth, from growing seedlings in copper-treated containers, recent work by Haywood et al. (2012) that updated Sung et al. (2010) indicated that seedlings grown in copper treated containers had greater height and volume growth than control seedlings 5 years after outplanting. These seedlings were outplanted on a Plinthaquic Paleudult (Ultisols) soil (Haywood et al. 2012) that experiences a high water table for a portion of each year. Interestingly, Vogel and Jokela (2011) report that copper was the most limiting micronutrient to southern pine growth on Alaquods (Spodosols), another soil that experiences a high water table but year round. While $\mathrm{Cu}$ availability is controlled by many interacting edaphic conditions, high water tables cause reducing conditions that further limit $\mathrm{Cu}$ availability (Sims and Patrick 1977). In addition, South et al. (2004) noted that adding $\mathrm{Cu}$ fertilizer to deficient soils before outplanting pine seedlings improved their second-year height growth. Further research is required to differentiate whether improvements in longleaf pine seedling growth are caused by copper-induced modifications to root architecture or by seedling translocation of copper loaded during nursery production; Dunn et al. (1997) observed higher Cu concentrations in foliage of copperpruned seedlings.

Although Mo was found to be a less important micronutrient affecting pine tree growth when compared with $\mathrm{Cu}$ (Vogel and Jokela 2011), the optimum concentrations of this nutrient in conifer seedlings remains unclear. Although we supplied Mo at $0.006 \mathrm{mg} \mathrm{L}^{-1}$, twice the rate used by Brissette et al. (1990) for longleaf pine, our observed concentrations were lower than those suggested by Landis et al. (1989) for container stock, closer to the levels for bareroot stock (Landis 1985), and within the range observed by South et al. (2005) for longleaf pine grown in a variety of containers. Relatively little has been published on Mo requirements in container conifers but the requirement appears to be species specific and root or whole plant concentrations may be a better indicator of sufficiency than foliar concentration (van den Driessche 1989). In our study, root concentrations of Mo varied sevenfold. Given this ambiguity, further work with Mo requirements in conifers, and longleaf pine in particular, seems warranted, especially considering that micronutrient deficiencies, including those by Mo, can reduce growth of pines in the southeastern USA (see Vogel and Jokela 2011).

To summarize, few pine species develop a grass stage, and those that do pose unique challenges during container nursery production because of their large taproots and stemless nature. Using longleaf pine seedlings grown in containers of four different volumes either coated with copper oxychloride or left untreated and fertilized at low, medium, or 
high levels of $\mathrm{N}$, we found that these strongly tap-rooted seedlings may benefit from production in larger volume containers. Although seedlings grew larger in response to increased $\mathrm{N}$ supply and increased container volume, seedlings did not approach RBI threshold values even at the highest rate of $\mathrm{N}$ fertilization and regardless of container size. This suggests that RBI may be more important for evaluating seedling quality of crops held into a second growing season, rather than for seedlings grown during a single season and promptly outplanted. In general, modifying root system morphology with copper oxychloride increased seedling root-collar diameter and tap root dry mass while decreasing total root volume. Copper treatment influenced photosynthesis more than did $\mathrm{N}$ rate, although results were opposite for chlorophyll levels in needles.

Acknowledgments This project was supported by the USDA Forest Service Southern Research Station, Rocky Mountain Research Station, and the National Center for Reforestation, Nurseries, and Genetic Resources. We thank B Bird (statistician, Rocky Mountain Research Station) and JP Barnett (emeritus scientist, Southern Research Station) for their contributions, as well as the associate editor and anonymous reviewers for their insightful comments.

\section{References}

[ASTM] American Society for Testing and Materials (1989) Standard test method for specifying color by the Munsell system. American Society for Testing and Materials. Annual book of ASTM standards D 1535-89

Aldrete A, Mexal JG, Phillips R, Vallotton AD (2002) Copper coated polybags improve seedling morphology for two nursery-grown Mexican pine species. For Ecol Manag 163:197-204

Aphalo P, Rikala R (2003) Field performance of silver-birch planting-stock grown at different spacing in containers of different volume. New For 25:93-108

Balisky AC, Salonius P, Walli C, Brinkman D (1995) Seedling roots and the forest floor: misplaced and neglected aspects of British Columbia's reforestation effort? For Chron 71:59-65

Barnett JP (1984) Top pruning and needle clipping of container-grown southern pine seedlings. In: Lantz C (ed) Proceedings of the southern nursery conference. USDA Forest Service, Southern Region, State \& Private Forestry, pp 39-45

Barnett JP (1989) Shading reduces growth of longleaf and loblolly pine seedlings in containers. Tree Plant Notes 40(1):23-26

Barnett JP (1999) Longleaf pine ecosystem restoration. J Sustain For 9:89-96

Barnett JP (2002) Longleaf pine: why plant it? Why use containers? In: Barnett JP, Dumroese RK, Moorhead DJ (eds) Proceedings of workshops on growing longleaf pine in containers-1999 and 2001. USDA Forest Service, Southern Research Station, Gen Tech Rep SRS-56, pp 5-7

Barnett JP, McGilvray JM (2002) Copper-treated containers influence root development of longleaf pine seedlings. In: Barnett JP, Dumroese RK, Moorhead DJ (eds) Proceedings of workshops on growing longleaf pine in containers-1999 and 2001. USDA Forest Service, Southern Research Station, Gen Tech Rep SRS-56, pp 24-26

Barnett JP, Hainds MJ, Hernandez GA (2002) Interim guidelines for growing longleaf seedlings in containers. In: Barnett JP, Dumroese RK, Moorhead DJ (eds) Proceedings of workshops on growing longleaf pine in containers-1999 and 2001. USDA Forest Service, Southern Research Station, Gen Tech Rep SRS-56, pp 27-29

Brissette JC, Elliott M, Barnett JP (1990) Producing container longleaf pine seedlings. In: Farrar RM Jr (ed) Proceedings of the symposium on the management of longleaf pine. USDA Forest Service, Southern Forest Experiment Station, Gen Tech Rep SO-75, pp 52-70

Brissette JC, Barnett JP, Landis TD (1991) Container seedlings. In: Duryea ML, Dougherty PM (eds) Forest regeneration manual. Springer, Dordrecht, pp 117-141

Burdett AN (1978) Control of root morphogenesis for improved mechanical stability in container-grown lodgepole pine. Can J For Res 8:483-486

Burdett AN (1979) A nondestructive method for measuring the volume of intact plant parts. Can J For Res 9:120-122

Burdett AN, Martin PAF (1982) Chemical root pruning of coniferous seedlings. HortScience 16:622-624 
Burdett AN, Coates H, Eremko R, Martin PAF (1986) Toppling in British Columbia's lodgepole pine plantations: significance, cause and prevention. For Chron 62:433-439

Davis AS, Ross-Davis AL, Dumroese RK (2011) Nursery culture impacts cold hardiness in longleaf pine (Pinus palustris) seedlings. Restor Ecol 19:717-719

Dong H, Burdett AN (1986) Chemical root pruning of Chinese pine seedlings raised in cupric sulfide impregnated paper containers. New For 1:67-73

Dumroese RK (2002) An outside perspective on growing longleaf pine-thoughts from a nursery manager in the Pacific Northwest. In: Barnett JP, Dumroese RK, Moorhead DJ (eds) Proceedings of workshops on growing longleaf pine in containers-1999 and 2001. USDA Forest Service, Gen Tech Rep SRS-56, pp 35-42

Dumroese RK, Wenny DL (1997) An assessment of ponderosa pine seedlings grown in copper-coated polybags. Tree Plant Notes 48(3):60-64

Dumroese RK, James RL, Wenny DL (2002) Hot water and copper coatings in reused containers decrease inoculum of Fusarium and Cylindrocarpon and increase Douglas fir seedling growth. HortScience 37:943-947

Dumroese RK, Parkhurst J, Barnett JP (2005) Controlled release fertilizer improves quality of container longleaf pine seedlings. In: Dumroese RK, Riley LE, Landis TD (tech coords) National proceedings, forest and conservation nursery associations-2004. USDA Forest Service, Proceedings RMRS-P-35, pp 3-8

Dumroese RK, Barnett JP, Jackson DP, Hainds MJ (2009) 2008 Interim guidelines for growing longleaf pine seedlings in container nurseries. In: Riley LE, Dumroese RK (tech coords) National proceedings, forest and conservation nursery associations-2008. USDA Forest Service, Proceedings RMRS-P-58, pp 101-107

Dunn GM, Huth JR, Lewty MJ (1997) Coating nursery containers with copper carbonate improves root morphology of five native Australian tree species used in agroforestry systems. Agrofor Syst 37: $143-155$

Fiedler HJ, Nebe F, Hoffman W (1973) Forstliche Pflanzenernährung und Düngung. G Fisher, Stuttgart

Grossnickle SC (2000) Ecophysiology of northern spruce species: the performance of planted seedlings. NRC Research Press, Ottawa 409

Hainds MJ (2002a) Marketing and seedling distribution of longleaf pine seedlings. In: Barnett JP, Dumroese RK, Moorhead DJ (eds) Proceedings of workshops on growing longleaf pine in containers-1999 and 2001. USDA Forest Service, Gen Tech Rep SRS-56, p 58

Hainds MJ (2002b) Longleaf seedling trends. In: Barnett JP, Dumroese RK, Moorhead DJ (eds) Proceedings of workshops on growing longleaf pine in containers-1999 and 2001. USDA Forest Service, Gen Tech Rep SRS-56, pp 3-4

Hainds MJ (2004) Establishing longleaf pine seedlings on agricultural fields and pastures. In: Connor KF (ed) Proceedings of the 12th biennial southern silvicultural research conference. USDA Forest Service, Gen Tech Rep SRS-71, pp 309-313

Haywood JD, Sung SS, Sword Sayer MA (2012) Copper root pruning and container cavity size influence longleaf pine growth through five growing season. South J Appl For 36:146-151

Heiskanen J (2005) Foliar colour as an indicator of foliar chlorophyll and nitrogen concentration and growth in Norway spruce seedlings. Scand J For Res 20:329-336

Jackson DP, Dumroese RK, Barnett JP (2012) Nursery response of container Pinus palustris seedlings to nitrogen supply and subsequent effects on outplanting performance. For Ecol Manag 265:1-12

Johnson JD (1984) A rapid technique for estimating total surface of pine needles. For Sci 30:913-921

Jose S, Jokela EJ, Miller DL (eds) (2006) The longleaf pine ecosystem-ecology, silviculture, and restoration. Springer, New York, p 438

Keeley JE (2012) Ecology and evolution of pine life histories. Ann For Sci 69:445-453

Kush JS, Meldahl RS, McMahon CK, Boyer WD (2004) Longleaf pine: a sustainable approach for increasing terrestrial carbon in the southern United States. Environ Manag 33(Suppl 1):S139-S147

Lambert DH, Weidensaul TC (1982) Copper requirements of container-grown conifer seedlings. Can J For Res 12:848-852

Landis TD (1985) Mineral nutrition as an index of seedling quality. In: Duryea ML (ed) Proceedings: evaluating seedling quality: principles, procedures, and predictive abilities of major tests. Oregon State Univ, Forest Research Lab, Corvallis, pp 29-48

Landis TD (1989) Mineral nutrients and fertilization. In: Landis TD, Tinus RW, McDonald SE, Barnett JP (eds) Seedling nutrition and irrigation. The container tree nursery manual, vol 4. USDA Forest Service, Ag Handbook 674, Washington, pp 1-67

Landis TD (2012) Managing surplus or holdover nursery stock. USDA Forest Service. For Nurs Notes 30(1):10-12 
Landis TD, Dumroese RK (2006) Applying the target plant concept to nursery stock quality. In: MacLennan L, Fennessy J (eds) Plant quality: a key to success in forest establishment. Proceedings of the National Council for Forest Research and Development (COFORD) conference, Dublin, Ireland, pp 1-10

Landis TD, van Steenis E (2000) Micronutrients: copper. Tree Plant Notes 49(3):44-48

Landis TD, Tinus RW, McDonald SE, Barnett JP (1989) Seedling nutrition and irrigation. The container tree nursery manual, vol 4. USDA Forest Service, Ag Handbook 674, Washington

Landis TD, Tinus RW, McDonald SE, Barnett JP (1990) Containers and growing media. The container tree nursery manual, vol 2. USDA Forest Service, Ag Handbook 674, Washington

Landis TD, Steinfeld DE, Dumroese RK (2010) Native plant containers for restoration projects. Nativ Plants J 11:341-348

Linder S (1980) Chlorophyll as an indicator of nitrogen status of seedlings. N Z J For Sci 10:166-175

Moran R, Porath D (1980) Chlorophyll determination in intact tissues using N, N'-dimethylformamide. Plant Physiol 65:478-479

Oliet JA, Artero F, Cuadros S, Puértolas J, Luna L, Grau JM (2012) Deep planting with shelters improves performance of different stocktype sizes under arid Mediterranean conditions. New For 43:925-939

Outcalt KW (2000) The longleaf pine ecosystem of the South. Nativ Plants J 1:42-44, 47-53

Pinto JR, Dumroese RK, Davis AS, Landis TD (2011a) Conducting seedling stocktype trials: a new approach to an old question. J For 109:293-299

Pinto JR, Marshall JD, Dumroese RK, Davis AS, Cobos DR (2011b) Establishment and growth of container seedlings for reforestation: a function of stocktype and edaphic conditions. For Ecol Manag 261:1879-1884

Pinto JR, Marshall JD, Dumroese RK, Davis AS, Cobos DR (2012) Photosynthetic response, carbon isotopic composition, survival, and growth of three stocktypes under water stress enhanced by vegetative competition. Can J For Res 42:333-344

Porra RJ, Thompson WA, Kriedemann PE (1989) Determination of accurate extinction coefficients and simultaneous equations for assaying chlorophylls a and b extracted with four different solvents: verification of the concentration of chlorophyll standards by atomic absorption spectroscopy. Biochim Biophys Acta 975:384-394

Ritchie GA, Landis TD, Dumroese RK, Haase DL (2010) Assessing plant quality. In: Landis TD, Dumroese RK, Haase DL (eds) Seedling processing, storage, and outplanting. The container tree nursery manual, vol 7. USDA Forest Service, Ag Handbook 674, Washington, pp 17-81

Ruehle JL (1985) The effect of cupric carbonate on root morphology of containerized mycorrhizal seedlings. Can J For Res 15:586-592

Salifu KF, Jacobs DF (2006) Characterizing fertility targets and multi-element interactions in nursery culture of Quercus rubra seedlings. Ann For Sci 63:231-237

Salonius P, Hallett R, Beaton K, French C (2002) Extended nursery rearing compromises field performance of container-reared conifer seedlings. Canadian Forest Service, Atlantic Forestry Centre, Info Rep M-X-214E, p 21

Saul GH (1968) Copper safely controls roots of tubed seedlings. Tree Plant Notes 19(1):7-9

Sims JL, Patrick WH Jr (1977) The distribution of micronutrient cations in soil under conditions of varying redox potential and $\mathrm{pH}$. Soil Sci Soc Am J 42:258-262

South DB, Mitchell RG (2006) A root-bound index for evaluating planting stock quality of container-grown pines. S Afr For J 207:47-54

South DB, Shelton J, Enebak SA (2001) Geotropic lateral roots of container-grown longleaf pine seedlings. Nativ Plants J 2:126-130

South DB, Carey WA, Johnson DA (2004) Copper deficiency in pine plantations in the Georgia coastal plain. Proceedings of the 12th biennial southern silvicultural research conference. USDA Forest Service, Gen Tech Rep SRS-71, pp 387-390

South DB, Harris SW, Barnett JP, Hainds MJ, Gjerstad DH (2005) Effect of container type and seedling size on survival and early height growth of Pinus palustris seedlings in Alabama, U.S.A. For Ecol Manag 204:385-398

Struve DK (1993) Effect of copper-treated containers on transplant survival and regrowth of four tree species. J Environ Hortic 11:196-199

Sung S-JS, Haywood JD, Sword-Sayer MA, Connor KF, Scott AD (2010) Effects of container cavity size and copper coating on field performance of container-grown longleaf pine seedlings. In: Stanturf JA (ed) Proceedings of the 14th biennial southern silvicultural research conference. USDA Forest Service, Gen Tech Rep SRS-GTR-121, pp 241-245

Svenson SE, Davies FT Jr (1992) Comparison of methods for estimating surface area of water-stressed and fully hydrated pine needle segments for gas exchange analysis. Tree Physiol 10:417-421 
Sword Sayer MA, Brissette JC, Barnett JP (2005) Root growth and hydraulic conductivity of southern pine seedlings in response to soil temperature and water availability after planting. New For 30:253-272

Sword Sayer MA, Haywood JD, Sung S-JS (2009) Cavity size and copper root pruning affect production and establishment of container-grown longleaf pine seedlings. For Sci 55:377-389

Sword Sayer MA, Sung S-JS, Haywood JD (2011) Longleaf pine root system development and seedling quality in response to copper root pruning and cavity size. South J Appl For 35:5-11

van den Driessche R (1989) Nutrient deficiency symptoms in container-grown Douglas-fir and white spruce seedlings. Forestry Canada and British Columbia Ministry of Forests. Forest Resource Development Agreement (FRDA) Rep 100. p 29

van den Driessche R (1991) Mineral nutrition of conifer seedlings. CRC Press, Boca Raton

van Steenis E (1994) Growing in copper treated containers requires greater awareness. British Columbia Ministry of Forests. Seed Seedl Ext Top 7(2):4-5

Vogel JG, Jokela EJ (2011) Micronutrient limitations in two managed southern pine stands planted on Florida spodosols. Soil Sci Soc Am J 75:1117-1124

Wenny DL, Woollen RL (1989) Chemical root pruning improves the root system morphology of containerized seedlings. West J Appl For 4:15-17 